\title{
Chapter 6 \\ Riparian Forests and Climate Change: Interactive Zone of Green and Blue Infrastructure
}

\author{
Futoshi Nakamura
}

\begin{abstract}
Riparian forests are recognized as green/blue infrastructure that provides various ecosystem services, including water transport, shade from sunlight energy, supply of leaf litter, input of terrestrial insect, delivery of large wood, maintenance of water quality, and corridors for wildlife. However, these forests have already experienced negative impacts from various anthropogenic stressors, such as forest cutting, agricultural development, river regulation, and dam construction. Moreover, the climate projections for the twenty-first century in Japan indicate that mean precipitation may increase by more than $10 \%$, and other projections predict an increase in the frequency of high-magnitude floods and a reduction in the discharge of snowmelt floods. In this chapter, we describe probable changes in the structure and function of riparian forests that might result and describe adaption strategies to reduce the potential impacts of climate change on stream and riparian ecosystems exacerbated by anthropogenic stressors.
\end{abstract}

Keywords Riparian zone - Climate change adaptation · Green/blue infrastructure · Ecological function · Ecosystem services · Restoration

\subsection{Introduction}

A "riparian forest" refers to a forest that is transversely distributed from a riverbank to its floodplain at the foot of adjacent hillslopes (Fig. 6.1). Riparian forests include not only forests associated with stream/river courses but also those around wetlands and lakeshores. Riparian forest communities can survive intensive and frequent disturbance regimes through physiological and structural adaptations while utilizing the materials (sediment, nutrients, and organic matter) trapped by these disturbance events in complex river geomorphic surfaces (i.e., secondary channels, point bars,

\footnotetext{
F. Nakamura $(\triangle)$

Laboratory of Ecosystem Management, Graduate School of Agriculture, Hokkaido University, Sapporo, Japan

e-mail: nakaf@for.agr.hokudai.ac.jp
}

F. Nakamura (ed.), Green Infrastructure and Climate Change Adaptation, Ecological Research Monographs, https://doi.org/10.1007/978-981-16-6791-6_6 


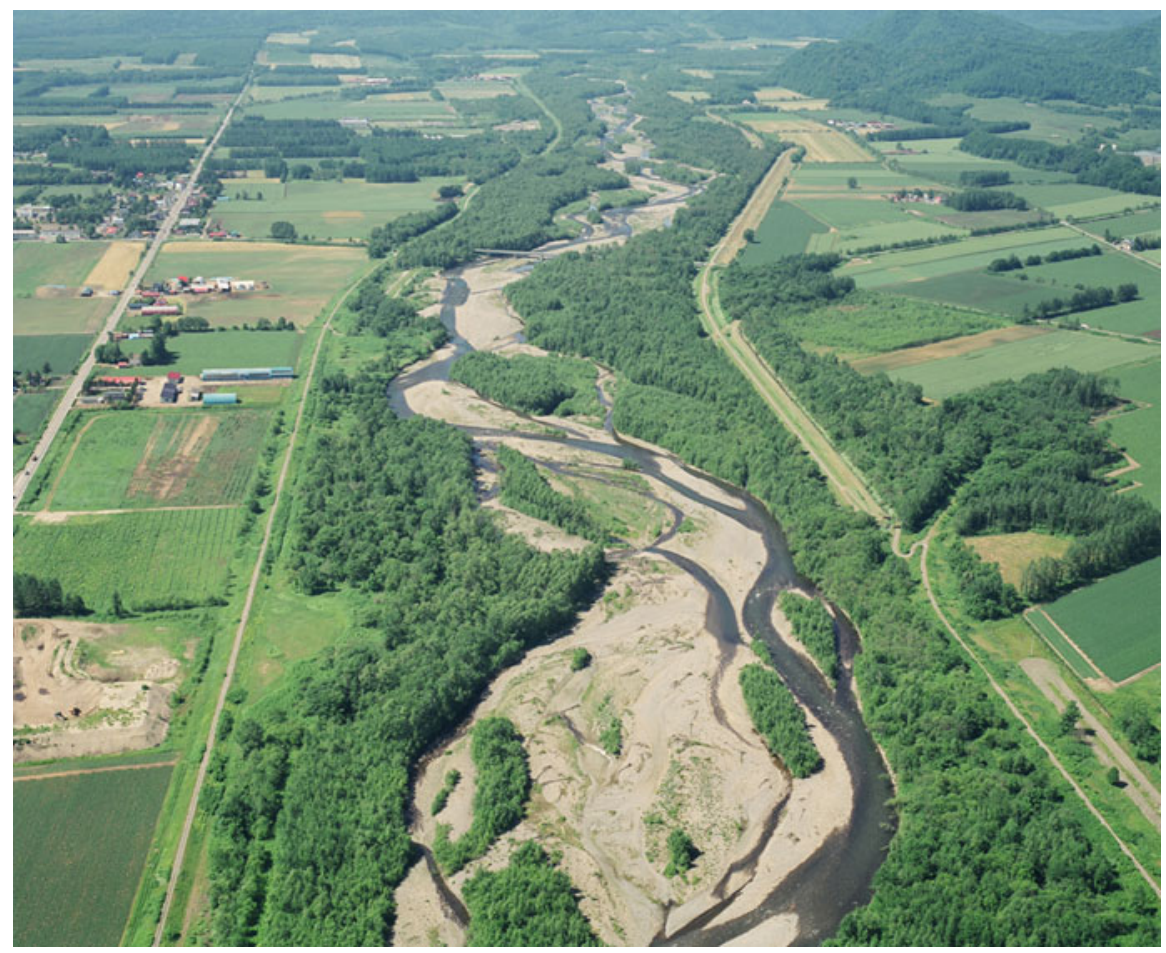

Fig. 6.1 Riparian forest of Satsunai River, Japan

and backswamps) as habitats for their growth and maintenance (Nakamura and Inahara 2007).

A riparian forest longitudinally extends from headwater streams to lowland rivers at the catchment scale (Niiyama 1987). The disturbance regime also changes from headwaters to low-gradient alluvial rivers (Nakamura et al. 2000; Nakamura and Swanson 2003) (Fig. 6.2). A dominant disturbance in headwater streams is mass movement, such as landslides and debris flows, characterized by their intensity but rare occurrence. In downstream, braided reaches, seasonal flood disturbances generate frequent high flows that form extensively developed geomorphic surfaces on floodplains. Low-gradient alluvial rivers in developing peat marshes rarely experience disturbances that result in landform alterations, although prolonged inundation in a marsh can cause substantial physiological stress to trees. Thus, a variety of disturbance types, frequencies, and intensities can be found at a catchment scale and may have diverse ecological consequences for riparian communities. In general, the structure and composition of riparian forests are determined by numerous environmental gradients, such as longitudinal and cross-sectional elevation, substrate (or soil) conditions, and disturbance frequency (Nakamura et al. 1997; Shin and Nakamura 2005; Sakio 1997). 


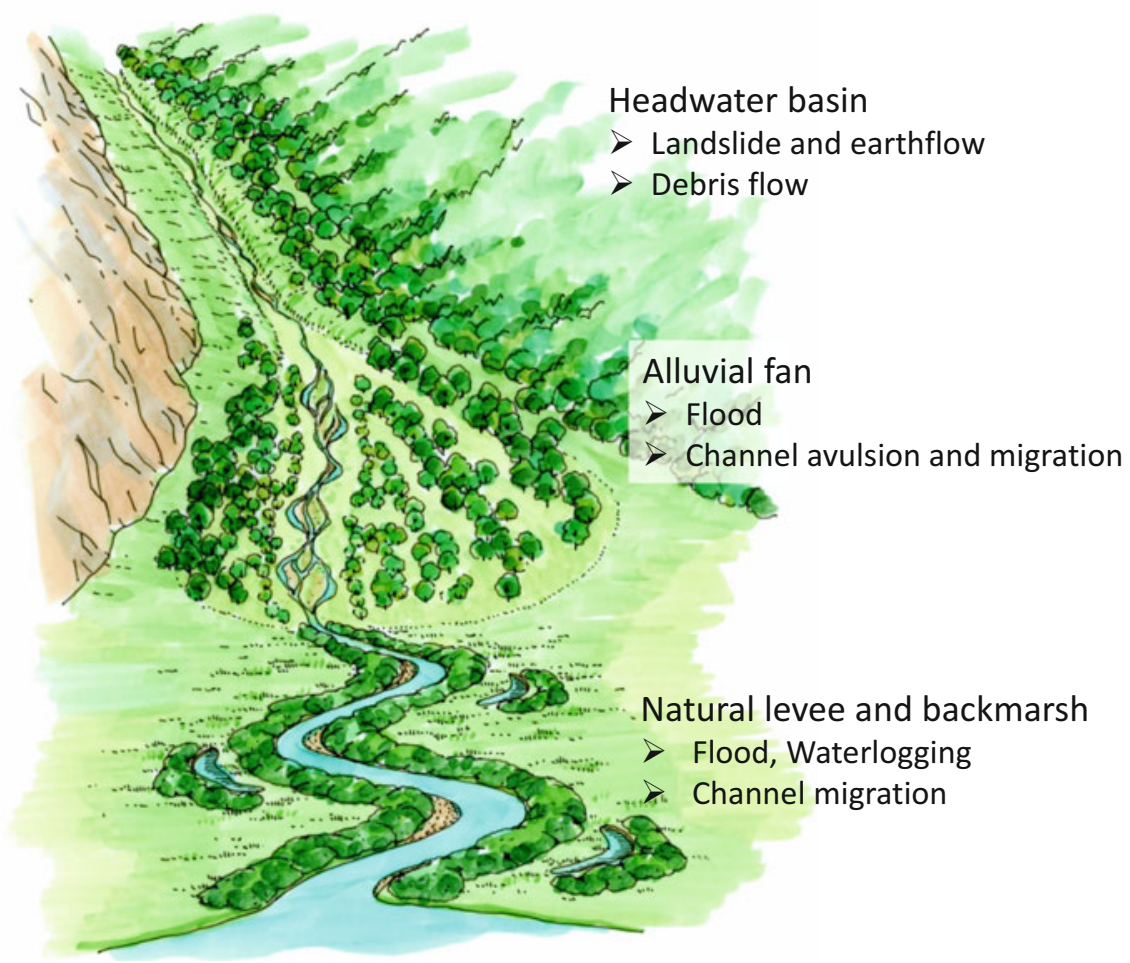

Fig. 6.2 Riparian forests and dominant disturbance regime from headwater basins to lowland alluvial rivers

Moreover, riparian forests and ponds in floodplains provide essential habitats for various terrestrial and aquatic organisms in all or specific stages of their life cycles. Thus, biodiversity in a riparian forest is generally higher than that in upland ecosystems, and riparian habitat specialists increase overall regional biodiversity (gamma diversity) at the catchment scale. Species richness, especially that of plants, is commonly higher in riparian forests than in upland forests, mainly because complex and diverse mosaics of habitat patches are created through land-water interactions (Amoros and Bornette 2002).

The species richness and diversity of macroinvertebrates and fishes in floodplain waterbodies vary along the gradients of hydrological connectivity (Gallardo et al. 2014; Schomaker and Wolter 2011; Ishiyama et al. 2014). Some waterbodies close to the main channel in a floodplain experience frequent floods, while other waterbodies more distant from the main channel may be disturbed only during high flood events or extremely large floods. Some waterbodies may be connected by drainage channels and/or small tributaries with other ponds or mainstems. These differences in connectivity alter the potential frequency of immigration and emigration of individuals and the physical and chemical characteristics of 
waterbodies. Consequently, taxon richness and diversity as well as species traits vary with connectivity gradients (Ishiyama et al. 2014). Riparian forests are recognized as a key habitat for the conservation of bird communities. Bird assemblages in riparian zones are distinctively different from those in neighboring areas, owing to differences in the plant communities (Yabuhara et al. 2019). Additionally, the species richness and abundance of birds are generally higher in riparian zones than in adjacent upland habitats due to the structural complexity of the riparian habitat.

Riparian forests provide essential ecological functions through a variety of mechanisms, including reducing sunlight and influencing in-stream primary production and water temperature, supplying food resources for aquatic invertebrates (e.g., fine organic matter, leaves, wood), supplying large wood to streams, filtering fine sediment and nutrients before their entry into streams, adding large roughness elements that reduce water velocity and protect stream banks, and providing migratory corridors for animals (Gregory et al. 1991; Naiman and Decamps 1997) (Fig. 6.3). A riparian forest is a unique landscape element that consists of diverse plant species, provides essential habitats for various terrestrial and aquatic organisms, and plays a pivotal role in the functioning of ecological processes between terrestrial and aquatic ecosystems. Thus, we can refer to a riparian forest as an "interactive zone of green and blue infrastructure" that should be preserved and restored for the twenty-first century. Here, green/blue infrastructure is defined as "a strategically planned network of natural and seminatural areas with other environmental features designed and managed to deliver a wide range of ecosystem services such as water purification, air quality, space for recreation and climate mitigation and adaptation" (European Commission 2016). Green infrastructure refers to terrestrial elements like trees, parks, hedgerows, and riparian vegetation, while blue infrastructure refers to aquatic elements such as rivers, wetlands, ponds, estuaries, and coasts.

However, in lowland areas of river basins, riparian forests occur on wet, fertile soil with flat topography. As a result, they have been exploited historically to harvest timber, construct forestry roads, cultivate farmlands, and develop urban

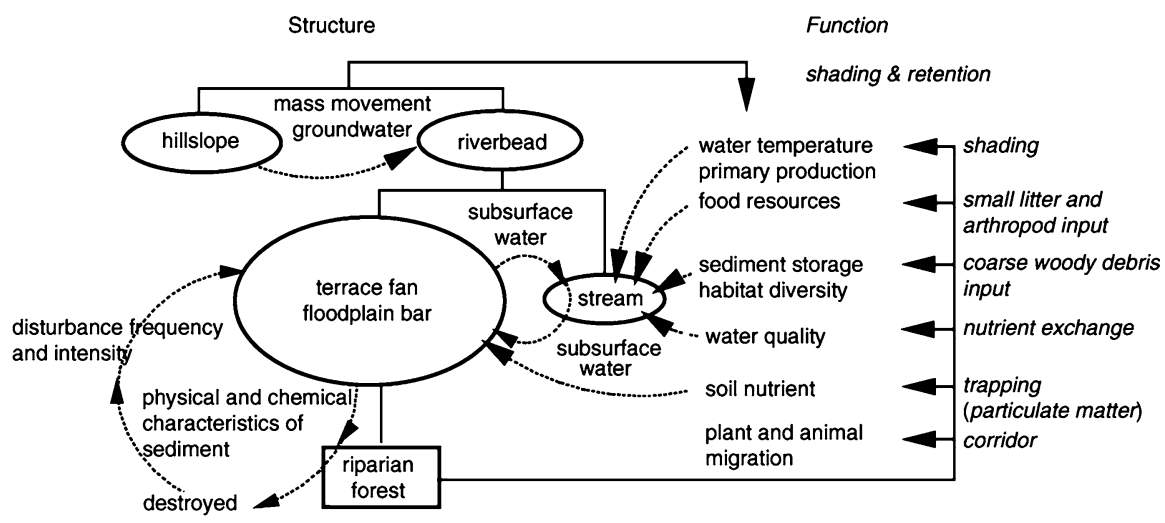

Fig. 6.3 Structures and functions of the riparian zone (from Nakamura and Yamada 2005) 


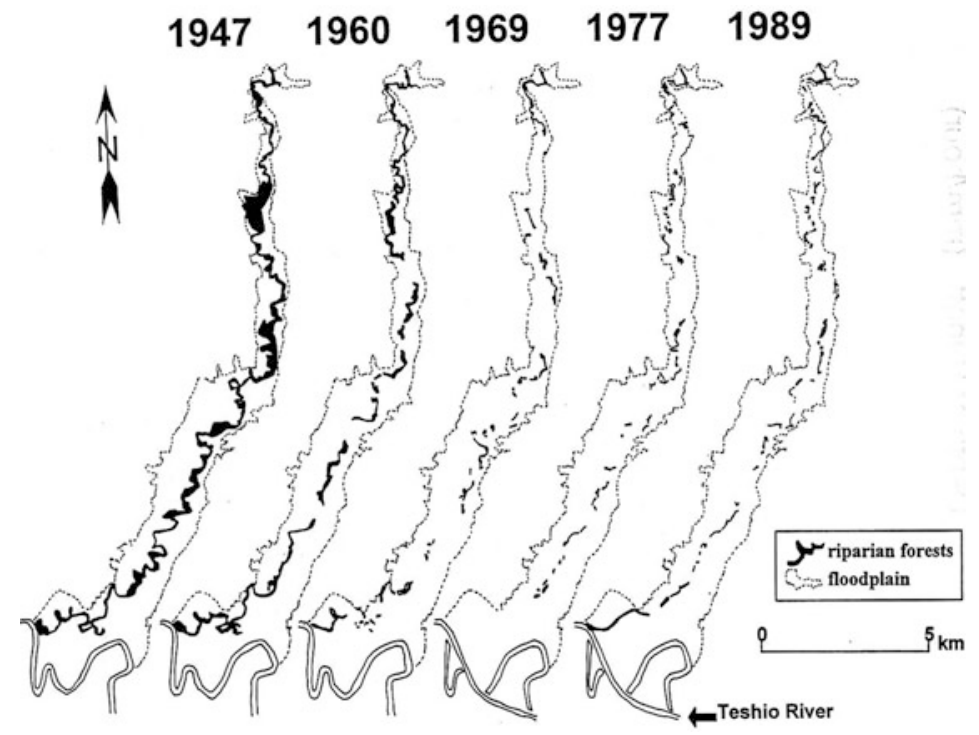

Fig. 6.4 Fragmentation of the riparian forests along the Toikanbetsu River, Japan (from Nagasaka and Nakamura 1999)

land uses (Sedell and Froggatt 1984; Nagasaka and Nakamura 1999) (Fig. 6.4). Dams greatly alter flow, sediment, and large wood regimes and thereby riparian vegetation (Nakamura 2017). The loss and degradation of riparian forests cause serious environmental problems; therefore, scientists and land managers have developed management approaches to conserve and restore riparian zones (e.g., riparian buffers, reforestation, channel remeandering, floodplain reconnection).

Another key driver that may greatly alter riparian forest ecosystems and their functions is climate change (Capon et al. 2013). In this chapter, we explore new roles of riparian forests under climate change scenarios and discuss a process for incorporating green/blue infrastructure for adaptation strategies to conserve biodiversity and address effects of climate change. Although this chapter focuses on riparian forests in Japanese landscapes, the derived adaptation strategies and principles are applicable to other parts of the world.

\subsection{Riparian Forest as an Interactive Zone of Green and Blue Infrastructure}

River and floodplain ecosystems are among the most sensitive of all ecosystems to climate change because they are tightly linked to atmospheric thermal regimes and global hydrological cycles, and they are affected by interactions between climate change and non-climatic stressors (e.g., farmland development, river regulation, 
impoundments, water pollution, urbanization, hydropower development) (Ormerod 2009; Thomas et al. 2016). According to the World Wide Fund for Nature (WWF) Living Planet Report 2014 Living Planet Index (LPI: a measure of the state of the world's biological diversity based on population trends in vertebrate species), the freshwater index has shown the greatest decline of any of the biome-based indices (WWF 2014).

Maintenance and enhancement of ecosystem services provided by riparian forests (Fig. 6.3) are important issues in biodiversity conservation and adaptation to climate change (Palmer et al. 2009). Stream temperature is the primary water quality variable that affects animal species distribution, phenology, and ecosystem processes and is expected to increase with rising air temperature under climate change (Thomas et al. 2016). Riparian forest canopies significantly reduce the amount of solar radiation reaching a stream surface. The removal of a riparian forest greatly increases insolation and thereby increases stream temperatures. A field study in northern Hokkaido streams suggested that the abundance of masu salmon is primarily limited by water temperature (Inoue et al. 1997). Masu salmon density in lowland grassland reaches, where the summer maximum water temperature is generally higher than $20^{\circ} \mathrm{C}$, was lower than density in nearby forest reaches. Effects of riparian canopies on stream water temperature have been examined in streams flowing through deciduous broad-leaved forests (Nakamura and Dokai 1989; Sugimoto et al. 1997). Nakamura and Dokai (1989) developed a heat budget to analyze the effect of riparian canopies and concluded that $86 \%$ of the daily total input of solar radiation is intercepted by the riparian canopy and its removal would result in a $4{ }^{\circ} \mathrm{C}$ increase in water temperature. Thus, the use of riparian forest shade to mitigate potential increases in stream temperature with climate change is a fundamental action in adaptation strategies for protecting cold-water species (Seavy et al. 2009; Wilby et al. 2010; Suzuki et al. 2021).

A riparian forest supplies various types of litterfall to streams (Benfield 1997). Litterfall is defined as allochthonous organic matter that enters streams from riparian vegetation. It includes leaves and leaf fragments, floral parts, bark, wood (stems, branches, twigs), cones and nuts, fruits, and other plant parts. Among these, the food quality of leaf litter is substantially greater than the others. Litter may reach a stream by directly falling into the stream or by laterally moving into the stream. Plant litter supplied from riparian forests is consumed by stream invertebrates. Terrestrial invertebrates fall into streams from riparian forests, providing important food resources for stream-dwelling fishes (Kawaguchi and Nakano 2001). In addition to the supply of leaf litter and terrestrial invertebrates into streams, large wood and twig accumulation, gravel bars, pools, and complex stream edges retain transported food resources for aquatic invertebrates and fishes. However, we expect more frequent, high flood peaks with climate change. In Japan, the fluctuation in yearly precipitation has increased since the 1970s, and the frequency of hourly heavy rains of $50 \mathrm{~mm}$ or more has increased (Ministry of the Environment et al. 2018). Rivers in developed countries have been regulated for over a century, and naturally meandering rivers have been altered to form straighten channelized rivers (Nagayama and Nakamura 2018). Thus, organic matter supplied from riparian 
forests into streams may be flushed downstream without retention on riverbeds, making it less available to stream biota.

Large wood is supplied from riparian forests into streams and rivers by various processes, such as landslides, debris flow, floods, windthrow, and bank erosion (Harmon et al. 2004). Large wood alters the structural and functional characteristics of stream channels, thereby influencing stream biota. In particular, the formation of pools by large wood has been investigated with reference to fish habitats (Fausch and Northcote 1992). Another important function of in-stream wood is modifying the movement and transformation of energy, nutrients, and food for stream-dwelling organisms. Step-pool sequences created by large wood provide storage sites for sediment, organic matter, and nutrients (Nakamura and Swanson 1993). It is widely recognized that trees growing along streambanks protect against bank erosion through their root system and create complex habitat along river margins (Gregory et al. 2019). Trees, however, will eventually fall into streams when flood power exceeds their tolerances. In this situation, riparian forests may be eroded and uprooted and transported downstream by floods. Wood-laden floods may destroy artificial levees, bridges, and houses along the river course, and the intensity and possibility of such disasters will increase with climate change. Thus, river managers have to balance the ecological benefits and geomorphic risks, both of which are important issues in a changing environment. The risks generated by floated wood should be avoided in urban areas, whereas the ecological functions of large wood should be sustained in rural and seminatural areas.

The effects of a riparian zone on water quality are well-known functions, particularly the reduction of sediment and nutrients before their entry into streams (Nakamura and Yamada 2005). Fine sediment eroded in uplands is efficiently removed by riparian vegetation that is $10-30 \mathrm{~m}$ in width, while nutrients such as nitrogen and phosphorus are efficiently removed by riparian vegetation that is 10-50 $\mathrm{m}$ in width. However, their effects vary with a number of local conditions, such as sedimentation rates, surface and subsurface drainage characteristics, soil characteristics (e.g., particle size composition and groundwater-level regulating redox potential), organic matter content, temperature, vegetation type (e.g., grass or forest, forest age, and density), nutrient loading from uplands, and slope steepness. Soil erosion and nutrient leaching from uplands are predicted to increase with increasing rainfall intensity under climate change (Jeppesen et al. 2009). Thus, the filtering function of riparian forests is a critical process in maintaining the health of river and wetland ecosystems.

Riparian forests are corridors in fragmented landscapes that connect healthy intact habitats and allow animals to move between them. Corridor use by bird and mammal species has been well investigated relative to that of other types of wildlife (Machtans et al. 1996; Hilty and Merenlender 2004). Terrestrial wildlife moves preferentially along or inhabits riparian forests. Wide, well-preserved corridors maintain a nearly complete species assemblage of the region. The home range of animals may change with climate change, driving animals to migrate more appropriately to higher-elevation areas. Thus, the current connectivity of riparian and stream corridors should be protected to facilitate climate-induced 
movement and restored when land use and dam construction impede their connectivity.

\subsection{Adaptation Strategies to Climate Change Using Riparian Green/Blue Infrastructure}

Riparian forests have been acknowledged as green/blue infrastructure that provides the various ecosystem services explained above. However, these forests have already experienced negative impacts from various anthropogenic stressors, such as forest cutting, agricultural development, river regulation, and dam construction. These stressors generally have detrimental effects on stream and floodplain biota, and climate change may magnify negative impacts (Palmer et al. 2009). Thus, strategies to conserve biodiversity at the landscape level must reduce or eliminate negative impacts of existing anthropogenic stressors on riparian ecosystems and anticipate the possible interactions of past impacts with climate change are key management needs for the future.

\subsubsection{Maintain River Dynamics Using Artificial Floods}

The structure and composition of riparian vegetation have been maintained by frequent migration of river channels and the active movement of sediment (Nakamura and Inahara 2007). Plant and animal species in streams and riparian zones are adapted to the dynamic features of rivers and floodplains (Poff et al. 1997). Additionally, the large wood produced by forests plays a critical role in providing a wide array of habitats for plants, invertebrates, and fishes (Nakamura et al. 2012; Nakano et al. 2018; Fausch and Northcote 1992). Thus, the dynamics of water, sediment, and large wood are three key components that maintain the regeneration of riparian plant species and thereby riparian ecosystems (Nakamura et al. 2017). However, water, sediment, and large wood regimes are greatly altered by dams and land use in Japan and other developed countries which results in drastic changes in the dynamic and interactive features of rivers and floodplains. These regime shifts of physical conditions convert diverse river habitats to stable, single-thread channels and increased forest establishment on gravel bars and floodplains (Nadler and Schumm 1981; Johnson 1994; Bejarano et al. 2011). Riparian forests play a pivotal role in maintaining stream and floodplain ecosystem, but they should be sustained by dynamic feature of the above three components. In natural rivers, pioneer tree species dominate gravel-bed rivers, and unvegetated gravel bars are essential sites for these species to germinate. In contrast, mid- and late-successional tree species start to colonize under pioneer trees and on gravel bars in dam-regulated rivers. The spread of late-successional 

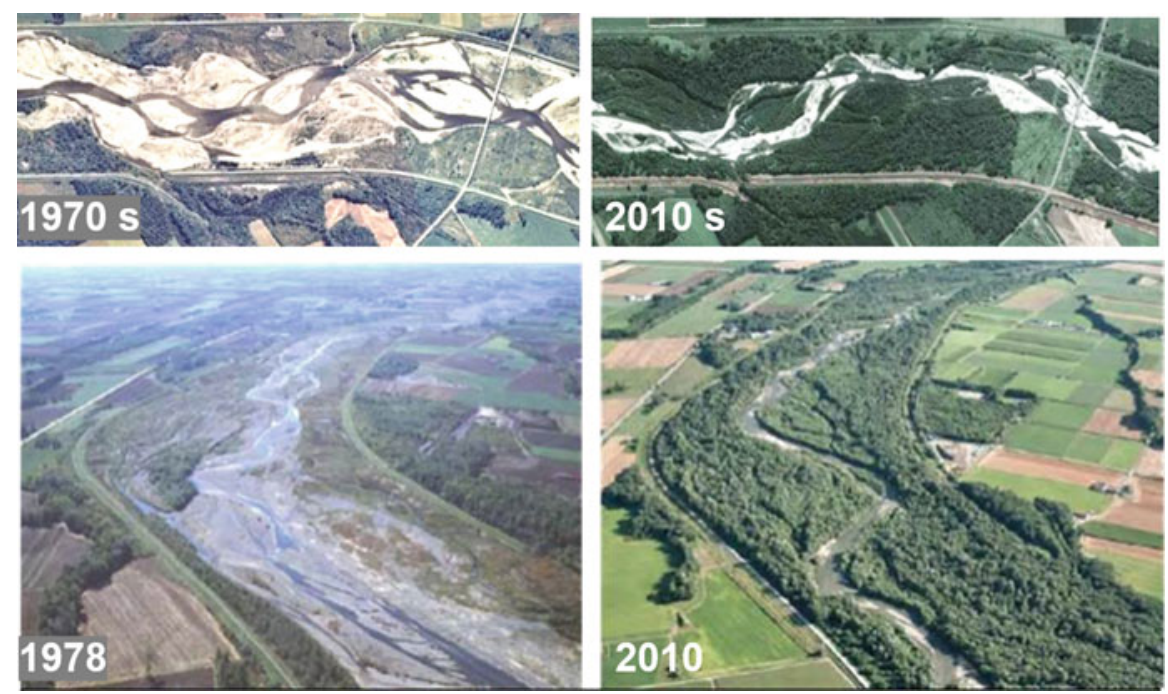

Fig. 6.5 Forest expansion over the gravel bars and floodplains of the Satsunai River

trees over gravel bars potentially threatens the survival of native species that are dependent on unvegetated habitat (Tiedemann and Rood 2015; Nakamura and Shin 2001).

One of the main causes of forest expansion in gravel rivers is dam construction and reservoir management (Takahashi and Nakamura 2011). Dams regulate water discharge by storing floodwater in their reservoirs and releasing water resources for power generation and agricultural use, which generally results in leveling the fluctuation in water discharge. The stabilization of water discharge and substantial reduction in floodwater discharge promote colonization of tree species on gravel bars and forest expansion over valley floors (Fig. 6.5). Dams and other human activities, such as channelization and revetment or spur-dike construction, promote channel incision and forest colonization over gravel bars and floodplains. Forest expansion causes two major problems for river management. One issue is an increase in channel roughness, which reduces its floodwater transport capacity, and the other issue is a reduction in gravel-bed habitat on which native, rare plant, and animal are dependent species (Nakamura et al. 2020; Yabuhara et al. 2015).

The climate projections for the twenty-first century in Japan indicate that mean precipitation may increase by more than $10 \%$ (Kimoto et al. 2005), and other projections predict an increase in the frequency of high-magnitude floods and a reduced discharge from snowmelt floods. With forest expansion and climate change, we expect more frequent inundation with floodwaters due to the increase in roughness elements and an increase in log-laden floods as riparian forest trees 


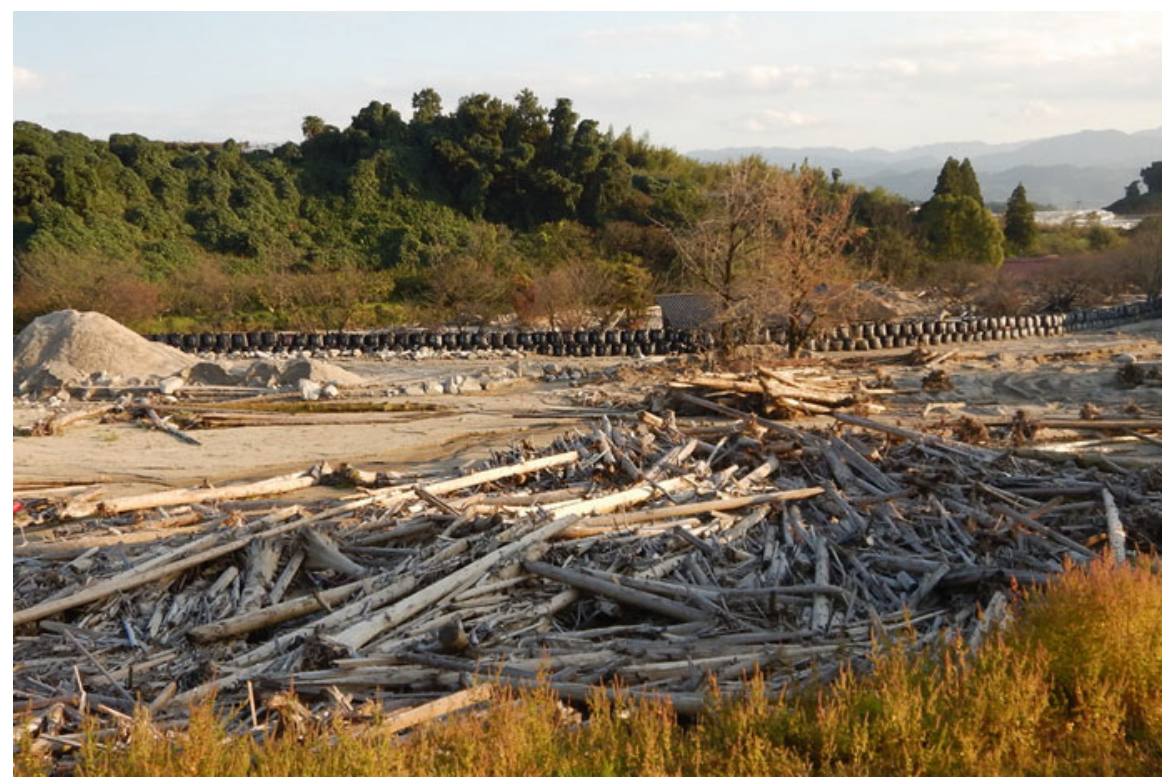

Fig. 6.6 Wood-laden flood caused by heavy rain in northern Kyushu in 2017

are removed by extreme floods (Fig. 6.6). Additionally, reduced discharge from snowmelt floods may cause recruitment failure of pioneer tree species such as Populus and Salix spp., which time their seed dispersal periods to the descending period of snowmelt floods (Nakamura and Inahara 2007).

Environmental flow regimes, including artificial floods, can be used to mitigate magnified effects of dams and climate change. In the Satsunai River, the Japanese government launched a restoration project in 2012 to partially restore its riparian ecosystems, releasing a maximum water volume of $120 \mathrm{~m}^{3} / \mathrm{s}$, with a 2-year return-period flood before dam construction (Nakamura et al. 2020). This was a large-scale experiment developed jointly with an interdisciplinary science team and river managers, who conducted monitoring and evaluations under an adaptive management scheme. Artificial floods have been initiated once a year at the end of June since 2012, and they have been synchronized with the seed dispersal period of Salix arbutifolia, which is endangered species and a high conservation priority for the project (Fig. 6.7). The project is successful so far in restoring a shifting mosaic of floodplain habitat patches and gravel bars and thereby in regenerating $S$. arbutifolia (Nakamura et al. 2020). With this project, an increase in dense forest cover has been minimized within the flood-disturbed area and regulated by the current flow regime, including artificial floods. 


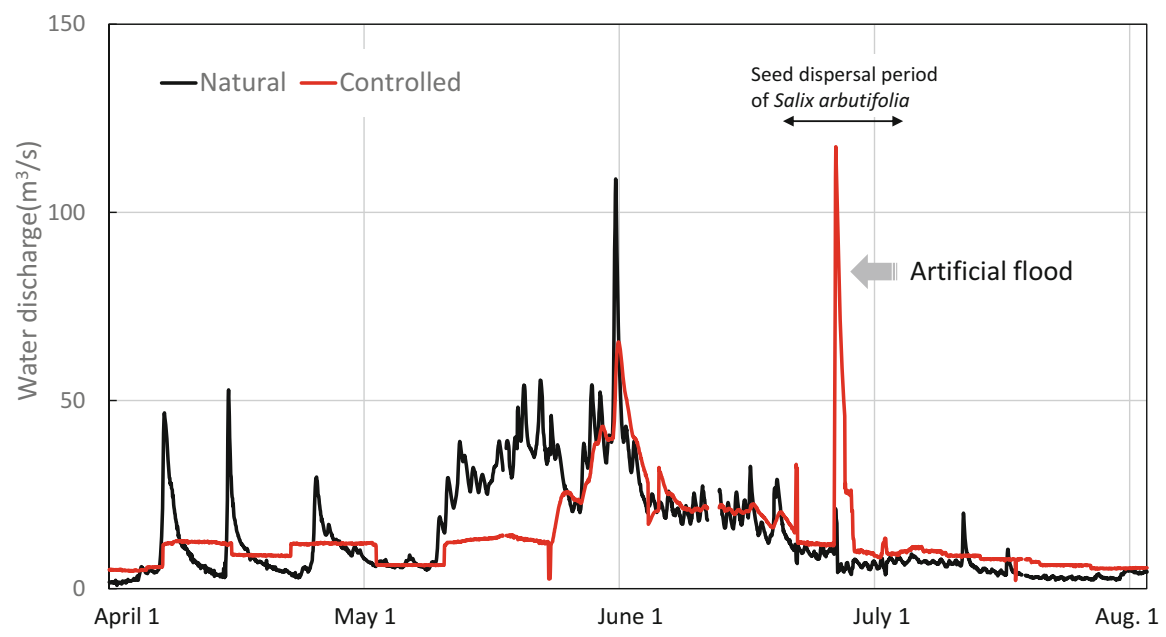

Hydrographs (water discharge) of natural flows (flows into the dam from the upper basin) and controlled flows (flows out of the dam)

Fig. 6.7 Hydrographs (water discharge) of natural flows (flows into the dam from the upper basin) and controlled flows with artificial floods (flows out of the dam) in the Satsunai River (from Nakamura et al. 2020)

\subsubsection{Maintain Riparian Forests Continuously from Headwater Streams to Lowland Rivers}

In Japan, considerable areas of hills and plains that were originally covered by forests have been converted to farmland, with streams and rivers being channelized to develop and conserve farmlands (Nagasaka and Nakamura 1999). One of the critical roles of riparian forests is the maintenance of cold water through their canopies; therefore, cold-water species, such as salmonids, are able to inhabit streams in Hokkaido, northern Japan. A laboratory experiment and field study indicated that feeding and growth of masu salmon decline when water temperatures reached $24{ }^{\circ} \mathrm{C}$ (Sato et al. 2001). Summer maximum water temperature is significantly related to the longitudinal extent of canopy removal (Sugimoto et al. 1997). This study concluded that removal of $1 \mathrm{~km}$ of canopy would be associated with a 2 $4{ }^{\circ} \mathrm{C}$ increase in water temperature, and a 6-km canopy removal would result in a $5-8{ }^{\circ} \mathrm{C}$ increase. Based on these data, they estimated a historical change in the summer maximum water temperature in a small stream and determined that stream temperature increased by $6{ }^{\circ} \mathrm{C}$ from $1947\left(22^{\circ} \mathrm{C}\right)$ to $1990\left(28{ }^{\circ} \mathrm{C}\right)$, with a sharp increase during the $1950 \mathrm{~s}$ as a result of rapid agricultural development. The results suggest that suitable habitat for masu salmon decreased historically as a result of these land use changes. 
Water temperature is expected to increase with increasing air temperature with climate change. However, studies that predict an increase in water temperature are scarce and limited by uncertainties associated with catchment geohydrology. In particular, porous volcanic rock is extensive across the Japanese archipelago, enhancing the contribution of groundwater discharge. This scenario insulates areas from exposure to sunlight energy and exchanges of latent and sensible heats and creates spring-fed streams with water temperatures that are cool in summer and warm in winter compared with those of runoff-fed streams. Spring-fed streams may provide refuges for cold-water fishes in hot summers under climate change conditions. Riparian forests will reduce the sunlight energy reaching the stream surface; therefore, maintaining continuous belts of riparian forests from headwater streams to lowland rivers is an adaptation strategy for climate change. In particular, the shading effect of a riparian forest canopy dominates in headwater streams where the stream width is relatively smaller than the size of the riparian forest canopy. In the case of Japanese streams, shading by riparian canopies is effective in streams less than $30 \mathrm{~m}$ in width (Nakamura and Dokai 1989). Thus, riparian cover should be protected along headwater streams as well as spring-fed streams to mitigate increases in air temperature. Such continuous belts of riparian forests will provide corridors for terrestrial birds and mammals to migrate to cooler environments.

\subsubsection{Remove or Improve Check Dams for Material Transport and Fish Migration}

Management agencies have constructed many check dams in headwater streams in Japan to prevent human lives and infrastructure from being affected by sedimentrelated disasters (e.g., landslides, debris flows, and hyperconcentrated flows) and to control erosion. Some check dams are not equipped with fish ladders, and prevent or reduce upstream migration of socially and economically important fish. Even if check dams have fish ladders, all ladders reduce passage to some degree, the continuity and dynamics of sediment transport are interrupted, and some organic matter produced from riparian forests is trapped by dams and buried by sediment. Check dams substantially alter the natural sediment regime, which sustains riparian forests in headwater basins (Nakamura et al. 2017).

Check dams greatly alter channel morphology and degrade salmonid habitats (Kishi and Maekawa 2009). In general, the channel above check dams becomes wider and shallower due to the wide dam face, and riparian trees become established farther away from the wide stream channel. Thus, the riparian canopy cover over the stream surface is reduced, and greater amounts of sunlight reach the stream surface and increase water temperature. On the Shiretoko Peninsula, currently designated as a World Natural Heritage Site, forest canopy cover over the stream surface is less than $10 \%$ in dam-installed reaches in contrast to $80-90 \%$ in natural reaches, and the 
maximum water temperature is $15-21^{\circ} \mathrm{C}$ in dam-installed reaches versus $12-17^{\circ} \mathrm{C}$ in natural reaches (Kishi and Maekawa 2009).

Check dams may exacerbate the thermal effects of global warming, resulting in greater heat energy exchange between air and waterbodies and even greater increase in stream temperature. To reduce the potential impacts of climate change on stream ecosystems exacerbated by anthropogenic stressors, check dams should be improved and modified to allow fish migration, restore the natural regime of sediment and organic matter, and ensure stream temperatures remain cool. Partial removal of check dams is a modification alternative that recovers quasi-natural systems and maintains disaster prevention functions. The center of the dam is cut to create a rectangular opening or slit (Nakamura and Komiyama 2010; Nagayama et al. 2020). The width of the opening is set to equal the low-flow channel width, thereby maintaining the natural transport of water, sediment, and organic matter under ordinary conditions and allowing fish to migrate upstream and downstream (Fig. 6.8). When debris flows arrive at the dam site, all sediment and turbid water cannot pass through the slit simultaneously, depositing sediment behind the dam due to the backwater effect. Subsequently, the trapped sediment behind the dam is gradually released from the slit during the descending limb of hydrographs and/or subsequent floodwaters. Riparian forests establish along the low-flow channel and their canopies cover the stream surface to a greater extent.

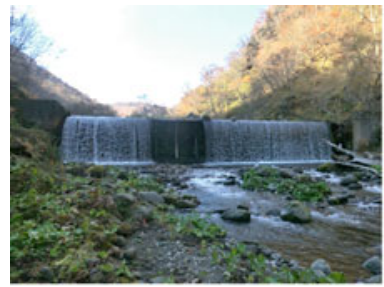

2014.10

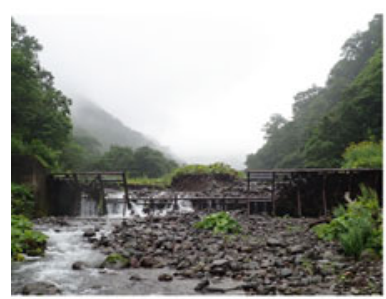

2019.8

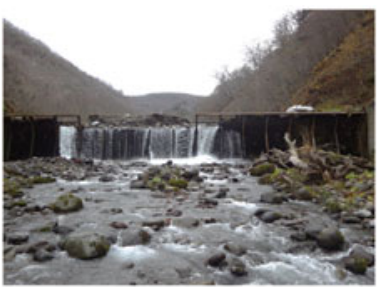

2018.11

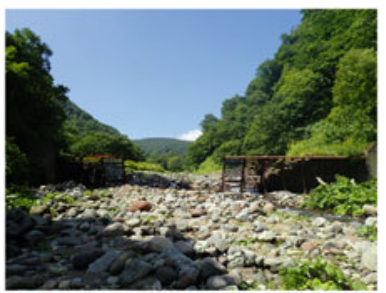

2020.8

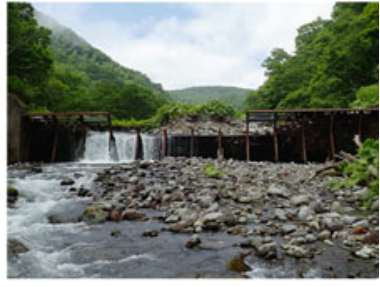

2019.6

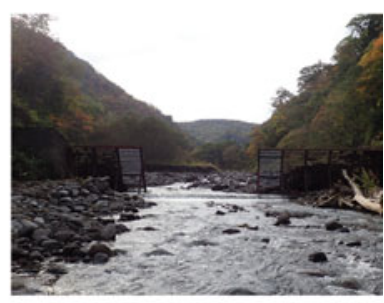

2020.10

Fig. 6.8 Dam modification and recovery of up- and downstream linkages at the Shiretoko World National Heritage Site 


\subsubsection{Broaden Riparian Forests and Remeander Rivers Where Possible}

Based on the climate change projection for 2040 under the RCP2.6 scenario in Japan, the average air temperature will increase by $2{ }^{\circ} \mathrm{C}$ from the current level, rainfall with a 100 - to 200 -year recurrence interval will increase by $10 \%$, and floodwater discharge will increase by $20 \%$. Thus, we must prepare for megafloods and associated environmental problems. We can expect an increase in the discharge of sediment, organic matter, and nutrients from upper basins. A study conducted in the Kushiro River basin, northern Japan, under the harshest climate change scenario (RCP 8.5), predicted that suspended sediment, total nitrogen, and total phosphorus will increase by 4.3-8.3-, 2.3-3.3-, and 2.6-4.2-fold, respectively, by the end of the twenty-first century (Ministry of the Environment 2020).

Adaptation actions to expand riparian vegetation cover on floodplains is a potential strategy to increase floodwater retention capacity and reduce floodwater velocity, which will reduce peak discharge of megafloods and increase the retention of transported materials (e.g., sediment, organic matter, and nutrients) in floodplains (Dybala et al. 2019). Remeandering artificially straightened rivers associated with the extension of floodplain areas will enhance the efficacy of this management strategy by increasing inundation and retention of carbon and nutrients in floodplains (Dahm et al. 1995; Nakamura et al. 2014) (Fig. 6.9). Movement of large wood into streams will increase with bank erosion associated with gradual movement of meandering river courses. Furthermore, large wood pieces that are transported by floodwater from upstream to downstream and that may destroy downstream infrastructure and houses during megafloods can be efficiently trapped on the outside of meandering rivers due to the inertial force of floodwater.

The adaptation strategies of extending floodplains and remeandering rivers also create various habitats for aquatic and terrestrial plants and animals. This approach is similar to the "Room for Rivers" concept in the EU (Buijse et al. 2002). The historical development of agricultural and urban land use converts naturally meandering rivers to straight river channels with revetments, disconnecting stream from their floodplain ecosystems. Adaptation measures will restore connectivity between rivers, ponds, and floodplain wetlands with increasing floodwater inundation. Ishiyama et al. (2014) investigated the effects of wetland connectivity on the species richness of aquatic invertebrates and fishes in agricultural landscapes. They found that the species richness of highly mobile groups of insects and fishes increased with increasing spatial connectivity. Thus, the frequent inundation of floodwater over riparian forests increases temporal and spatial connectivity among various waterbodies in floodplains and rivers. 


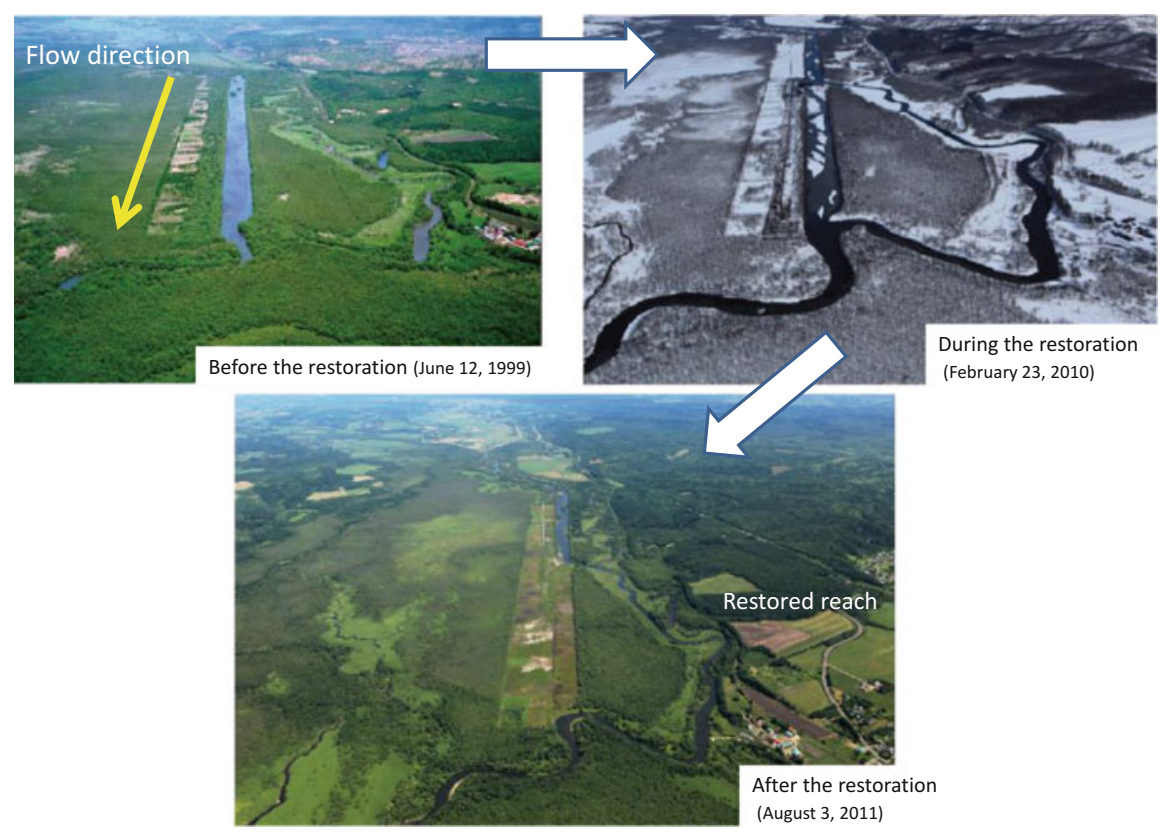

Fig. 6.9 Meander restoration in the Kushiro wetlands. The top left-hand photograph shows a 1.6$\mathrm{km}$ stretch of the main channel before it was restored by reconnecting the remaining former cutoff channel and backfilling the straightened reach (from Nakamura et al. 2014)

\subsection{Conclusion}

A riparian forest is regarded as an "interactive zone of green and blue infrastructure," and should be preserved and restored for the twenty-first century because it provides essential habitats for plant and animals and precious ecological functions in a changing environment. However, forests have already experienced negative impacts from various anthropogenic stressors, such as forest cutting, agricultural development, and river regulation due to its high productivity and geomorphic setting close to rivers. However, predictions of future climate change and associated impacts on biodiversity and ecosystem services project that the interaction of anthropogenic stressors and climate change will magnify those impacts. If those stressors are not reduced in the future, biodiversity and riparian ecosystems would not be sustained and important ecosystem services would be lost. Thus, active management and conservation strategies should be implemented to lessen non-climate stressors. Ecological restoration projects conducted throughout the world to protect and restore biodiversity and ecosystem services will be essential components of adaptation strategies for climate change in the future. 
Acknowledgments The author deeply appreciates all thoughtful comments and suggestions made by Dr. Stanley Gregory that significantly improve the quality of the original manuscript. This research was funded by the Environment Research and Technology Development Funds (4-1504 and 4-1805) of the Ministry of the Environment of Japan.

\section{References}

Amoros C, Bornette G (2002) Connectivity and biocomplexity in waterbodies of riverine floodplains. Freshw Biol 47:761-776

Bejarano DM, Nilsson C, del Tanago GM, Marchamalo M (2011) Responses of riparian trees and shrubs to flow regulation along a boreal stream in northern Sweden. Freshw Biol 56:853-866

Benfield EF (1997) Comparison of litterfall input to streams. J N Am Benthol Soc 16:104-108

Buijse AD, Coops H, Staras M, Jans LH, Van Geest GJ, Grift RE et al (2002) Restoration strategies for river floodplains along large lowland rivers in Europe. Freshw Biol 47(4):889-907

Capon SJ, Chambers LE, Mac Nally R, Naiman RJ, Davies P, Marshall N et al (2013) Riparian ecosystems in the 21st century: hotspots for climate change adaptation? Ecosystems 16(3):359381

Dahm CN, Cummins KW, Valett HM, Coleman RL (1995) An ecosystem view of the restoration of the Kissimmee River. Restor Ecol 3:225-238

Dybala KE, Matzek V, Gardali T, Seavy NE (2019) Carbon sequestration in riparian forests: a global synthesis and meta-analysis. Glob Chang Biol 25(1):57-67

European Commission (2016) Supporting the implementation of green infrastructure, Rotterdam

Fausch KD, Northcote TG (1992) Large woody debris and salmonid habitat in a small coastal British Columbia stream. Can J Fishery Aquat Sci 49:682-693

Gallardo B, Doledec S, Pallex A et al (2014) Response of benthic macroinvertebrates to gradients in hydrological connectivity: a comparison of temperate, subtropical, Mediterranean and semiarid river floodplains. Freshw Biol 59:630-648

Gregory SV, Swanson FJ, McKee WA, Cummins KW (1991) An ecosystem perspective of riparian zones. Bioscience 41:540-551

Gregory SV, Wildman R, Hulse D, Ashkenas L, Boyer K (2019) Historical changes in hydrology, geomorphology, and floodplain vegetation of the Willamette River, Oregon. River Res Appl 35(8):1279-1290

Harmon ME, Franklin JF, Swanson FJ, Sollins P, Gregory SV, Lattin JD et al (2004) Ecology of coarse woody debris in temperate ecosystems. Adv Ecol Res 34:59-234

Hilty JA, Merenlender AM (2004) Use of riparian corridors and vineyards by mammalian predators in northern California. Conserv Biol 18:126-135

Inoue M, Nakano S, Nakamura F (1997) Juvenile masu salmon (Oncorhynchus masou) abundance and stream habitat relationships in northern Japan. Can J Fish Aquat Sci 54:1331-1341

Ishiyama N, Akasaka T, Nakamura F (2014) Mobility-dependent response of aquatic animal species richness to a wetland network in an agricultural landscape. Aquat Sci 76:437-449

Jeppesen E, Kronvang B, Meerhoff M, Søndergaard M, Hansen KM, Andersen HE et al (2009) Climate change effects on runoff, catchment phosphorus loading and lake ecological state, and potential adaptations. J Environ Qual 38(5):1930-1941

Johnson WC (1994) Woodland expansion in the Platte River, Nebraska: patterns and causes. Ecol Monogr 64:45-84

Kawaguchi Y, Nakano S (2001) Contribution of terrestrial invertebrates to the annual resource budget for salmonids in forest and grassland reaches of a headwater stream. Freshw Biol 46:303-316

Kimoto M, Yasutomi N, Yokoyama C, Emori S (2005) Projected changes in precipitation characteristics around Japan under the global warming. SOLA 1:085-088. https://doi.org/ $10.2151 /$ sola.2005-023 
Kishi D, Maekawa K (2009) Stream-dwelling Dolly Varden (Salvelinus malma) density and habitat characteristics in stream sections installed with low-head dams in the Shiretoko Peninsula, Hokkaido, Japan. Ecol Res 24(4):873-880

Machtans CS, Villard M, Hannon SJ (1996) Use of riparian buffer strips as movement corridors by forest birds. Conserv Biol 10:1366-1379

Ministry of the Environment, Ministry of Education, Culture, Sports, Science and Technology, Ministry of Agriculture, Forestry and Fisheries, Ministry of Land, Infrastructure, Transport and Tourism and Meteorological Agency of Japan (2018) Kikou henndou no kannsoku yosoku eikyou hyouka nikannsuru tougou report 2018 nihonn no kikouhenndou to sono eikyou [Consolidated report on observations, projections and impact assessments of climate change: climate change and its impacts in Japan]. http://www.env.go.jp/earth/tekiou/report2018_full.pdf

Ministry of the Environment of Japan (2020) Final reports of regional adaptation consortium project. 1-6

Nadler CT, Schumm SA (1981) Metamorphosis of South Platte and Arkansas Rivers, Eastern Colorado. Phys Geogr 2:95-115

Nagasaka A, Nakamura F (1999) The influences of land-use changes on hydrology and riparian environment in a northern Japanese landscape. Landsc Ecol 14:543-556

Nagayama S, Nakamura F (2018) The significance of meandering channel to habitat diversity and fish assemblage: a case study in the Shibetsu River, northern Japan. Limnology 19:7-20

Nagayama S, Ishiyama N, Seno T, Kawai H, Kawaguchi Y, Nakano D, Nakamura F (2020) Time series changes in fish assemblages and habitat structures caused by partial check dam removal. Water 12(12):3357

Naiman RJ, Decamps H (1997) The ecology of interfaces: riparian zones. Annu Rev Ecol Syst 28:621-658

Nakamura F, Dokai T (1989) Estimation of the effect of riparian forest on stream temperature based on heat budget. J Jpn For Soc 71:387-394. (in Japanese with English summary)

Nakamura F, Swanson FJ (1993) Effects of coarse woody debris on morphology and sediment storage of a mountain stream system in western Oregon. Earth Surf Process Landf 18:43-61

Nakamura F, Yajima T, Kikuchi S (1997) Structure and composition of riparian forests with special reference to geomorphic site conditions along the Tokachi River, northern Japan. Plant Ecol 133:209-219

Nakamura F, Swanson FJ, Wondzell SM (2000) Disturbance regimes of stream and riparian systems - a disturbance-cascade perspective. Hydrol Process 14:2849-2860

Nakamura F, Shin N (2001) The downstream effects of dams on the regeneration of riparian tree species in northern Japan. Geomorphic processes and riverine habitat (Dorava $\mathrm{J} \mathbf{M}$, Montgomery D R, Palcsak B and Fitzpatrick F A eds.). AGU Water Sci Appl 4:173-181. ISBN: 0-87590-353-3

Nakamura F, Swanson FJ (2003) Dynamics of wood in rivers in the context of ecological disturbance. The ecology and management of wood in world rivers (Gregory S V, Boyer K L and Gurnell AM eds.). Symp 37:279-297. ISBN: 1-888569-56-5

Nakamura F, Yamada H (2005) The effects of pasture development on the ecological functions of riparian forests in Hokkaido in northern Japan. Ecol Eng 24:539-550

Nakamura F, Inahara S (2007) Fluvial geomorphic disturbances and life history traits of riparian tree species. In: Johnson EA, Miyanishi K (eds) Plant disturbance ecology: the process and the response. Academic Press, pp 283-310. ISBN: 978-0-12-088778-1

Nakamura F, Komiyama E (2010) A challenge to dam improvement for the protection of both salmon and human livelihood in Shiretoko, Japan's third natural heritage site. Landsc Ecol Eng 6:143-152

Nakamura F, Fuke N, Kubo M (2012) Contributions of large wood to the initial establishment and diversity of riparian vegetation in a bar-braided temperate river. Plant Ecol 213:735-747

Nakamura F, Ishiyama N, Sueyoshi M, Negishi J, Akasaka T (2014) The significance of meander restoration for the hydrogeomorphology and recovery of wetland organisms in the Kushiro River, a lowland river in Japan. Restor Ecol 22:544-554 
Nakamura F, Seo JIL, Akasaka T, Swanson FJ (2017) Large wood, sediment, and flow regimes: their interactions and temporal changes caused by human impacts in Japan. Geomorphology 279:176-187

Nakamura F, Watanabe Y, Negishi J, Akasaka T, Yabuhara Y, Terui A, Yamanaka S, Konno M (2020) Restoration of the shifting mosaic of floodplain forests under a flow regime altered by a dam. Ecol Eng 157:105974

Nakano D, Nagayama S, Kawaguchi Y, Nakamura F (2018) Significance of the stable foundations provided and created by large wood for benthic fauna in the Shibetsu River, Japan. Ecol Eng 120:249-259

Niiyama K (1987) Distribution of Salicaceae species and soil texture of habitats along the Ishikari River. Jpn J Ecol 37:163-174. (in Japanese with English summary)

Ormerod SJ (2009) Climate change, river conservation and the adaptation challenge. Aquat Conserv 19:609-613

Palmer MA, Lettenmaier DP, Poff NL, Postel SL, Richter B, Warner R (2009) Climate change and river ecosystems: protection and adaptation options. Environ Manag 44(6):1053-1068

Poff LR, Allan JD, Bain MB, Karr JR, Prestegaard KL, Richter BD, Sparks RE, Stromberg JC (1997) The natural flow regime. Bioscience 47:769-784

Sakio H (1997) Effects of natural disturbance on the regeneration of riparian forests in a Chichibu Mountains, Central Japan. Plant Ecol 132:181-195

Sato H, Nagata M, Takami T, Yanai S (2001) Shade effect of riparian forest in controlling summer stream temperature: impact on growth of masu salmon juveniles (Oncorhynchus masou Brevoort). J Jpn For Soc 83:22-29. (in Japanese with English Summary)

Schomaker C, Wolter C (2011) The contribution of long-term isolated water bodies to floodplain fish diversity. Freshw Biol 56:1469-1480

Seavy NE, Gardali T, Golet GH, Griggs FT, Howell CA, Kelsey R et al (2009) Why climate change makes riparian restoration more important than ever: recommendations for practice and research. Ecol Restor 27(3):330-338

Sedell JR, Froggatt JL (1984) Importance of streamside forests to large rivers: the isolation of the Willamette River, Oregon, U. S. A., from its floodplain by snagging and streamside forest removal. Verh Int Ver Limnol 22:1828-1834

Shin N, Nakamura F (2005) Effects of fluvial geomorphology on riparian tree species in Rekifune River, northern Japan. Plant Ecol 178:15-28

Sugimoto S, Nakamura F, Ito A (1997) Heat budget and statistical analysis of the relationship between stream temperature and riparian forest in the Toikanbetsu River basin, northern Japan. J For Res 2:103-107

Suzuki K, Ishiyama N, Koizumi I, Nakamura F (2021) Combined effects of summer water temperature and current velocity on the distribution of a cold-water-adapted sculpin (Cottus nozawae). Water 13:975

Takahashi M, Nakamura F (2011) Impacts of dam-regulated flows on channel morphology and riparian vegetation: a longitudinal analysis of Satsunai River. Jpn Landsc Ecol Eng 7:65-77

Thomas SM, Griffiths SW, Ormerod SJ (2016) Beyond cool: adapting upland streams for climate change using riparian woodlands. Glob Chang Biol 22(1):310-324

Tiedemann RB, Rood SB (2015) Flood flow attenuation diminishes cotton-wood colonization sites: an experimental test along the Boise River, USA Ecohydrology. https://doi.org/10.1002/ eco. 1619

Wilby RL, Orr H, Watts G, Battarbee RW, Berry PM, Chadd R et al (2010) Evidence needed to manage freshwater ecosystems in a changing climate: turning adaptation principles into practice. Sci Total Environ 408(19):4150-4164

WWF (2014) Living planet report 2014. https://www.wwf.or.jp/activities/data/ WWF_LPR_2014.pdf

Yabuhara Y, Yamaura Y, Akasaka T, Nakamura F (2015) Predicting long-term changes in riparian bird communities in floodplain landscapes. River Res Appl 31:109-119 
Yabuhara Y, Yamaura Y, Akasaka T, Yamanaka S, Nakamura F (2019) Seasonal variation in patch and landscape effects on forest bird communities in a lowland fragmented landscape. For Ecol Manag 454:117-140

Open Access This chapter is licensed under the terms of the Creative Commons Attribution 4.0 International License (http://creativecommons.org/licenses/by/4.0/), which permits use, sharing, adaptation, distribution and reproduction in any medium or format, as long as you give appropriate credit to the original author(s) and the source, provide a link to the Creative Commons license and indicate if changes were made.

The images or other third party material in this chapter are included in the chapter's Creative Commons license, unless indicated otherwise in a credit line to the material. If material is not included in the chapter's Creative Commons license and your intended use is not permitted by statutory regulation or exceeds the permitted use, you will need to obtain permission directly from the copyright holder.

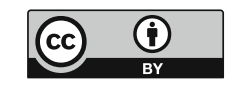

